\title{
CARBONATE CLASTS FROM CRETACEOUS CONGLOMERATE DEPOSITS OF THE POSTĂVARU MASSIF (SOUTHERN CARPATHIANS, ROMANIA) - DEPOSITIONAL ENVIRONMENTS AND BIOSTRATIGRAPHIC REMARKS
}

\author{
Sergiu Șerban ${ }^{1}$, Cristian Victor Mircescu ${ }^{1 *}$, Răzvan Ungureanu ${ }^{3} \&$ Ioan I. Bucur ${ }^{1,2}$
}

Received: 15 September 2020 / Accepted: 28 October 2020 / Published online: 9 November 2020

\begin{abstract}
The objective of this study is to describe the composition of the carbonate elements from the upper AlbianCenomanian Postăvaru Conglomerates. Eight sections were studied. Two major types of conglomerates are identified in the field and thin sections: polymictic orthoconglomerates and paraconglomerates. Carbonate clasts are dominant in both types of conglomerates. Other subordinated clasts are composed of quartzites, sericite-chlorite schists and gneisses. Facies data allow reconstructing the depositional environments, while microfossil assemblages were used to establish the age of the studied carbonate clasts. The identified microfacies characterize a large variety of depositional environments, ranging from basin to shallow water environments (platform margin and inner platform depositional settings). The identified microfossil associations are indicative for three biostratigraphic intervals: KimmeridgianTithonian, Tithonian-Berriasian and Berriasian-? lower Valanginian..
\end{abstract}

Keywords: Microfacies; Microfossils; Carbonate clasts; Conglomerates; Jurassic; Cretaceous

\section{INTRODUCTION}

The studied area belongs to the Getic Domain (Southern Carpathians). The sedimentary succession from the Postăvaru Massif is part of the „Braşov Series, (Patrulius, 1969). This sedimentary unit forms extensive outcrops around Brașov city (Postăvaru, Piatra Mare, Măgura Codlei), Piatra Craiului Massif, and the Dâmbovicioara Area or the Bucegi Mountains. Several authors have studied the geology of this unit from the Carpathian Bend Zone (Jekelius, 1920; Oncescu, 1943; Popescu, 1966; Patrulius, 1969; Bucur, 1978; Patrulius et al., 1980). More recent studies (post 1990) focused on the carbonate successions from the Piatra CraiuluiDâmbovicioara region (Bucur et al., 2009; Pleș et al., 2013; Grădinaru et al., 2016; Săsăran et al., 2017; Mircescu et al., 2019). Conglomerate deposits were described from the same area by Ungureanu et al. (2015; 2017 ; 2019). Their contribution was centered on reconstructing the source area of the carbonate clasts and on Aptian conglomerate facies description.

The main objective of this paper is to describe the lithological and micropaleontological composition of the carbonate clasts from the upper Albian-Cenomanian Postăvaru Conglomerates. Carbonate clasts paleoenvironmental reconstruction is performed for the first time in the study area. The studied outcrops are situated in the following locations: Groapa Dracului, Poiana RuiaCabana Postăvaru, Poiana Brașov-Poiana Mare, Poiana Mare, Lamba Mare, Poiana Cristianului, and the road to Braşov (Fig. 1 A-H). The geology of the Postăvaru
Massif was thoroughly decribed by Săndulescu (1964). This author described the lithological composition of the Postăvaru Conglomerates by mentioning the petrographic origin of their clasts. In addition, the author discusses in detail the stratigraphic uncertainties arising at the contact between these conglomerates and other Cretaceous deposits (sandstones and marls). However, a detailed microfacies and micropaleontological analysis of the carbonate clasts from the Postăvaru Conglomerates was not undertaken at the time. This study represents a preliminary stage for future detailed research in the area.

\section{GEOLOGICAL FRAMEWORK}

The Postăvaru Massif comprises the main mountainous unit bordering the southeastern part of the Braşov Depression. Meschendorfer (1860) and Herbich (1878) were the first authors who published important information regarding the geology of this area. Jekelius (1915; 1916; 1938) studied in detail the sedimentology of this unit by implementing a series of modern stratigraphic approaches. As mentioned previously, Săndulescu (1964) thoroughly described the geology of the Postăvaru Massif by mentioning the most important tectonic compartments (Postăvaru, Brașov, Cristian and Râşnov), lithostratigraphic units and their sedimentological features. The metamorphic basement belongs to the Leaota Group and crops out only in the western part of the Postăvaru Massif, in the Pârâul Comorii area. The Anisian-Cenomanian sedimentary cover is intensely affected by overthrusting

\footnotetext{
${ }^{1}$ Babeş-Bolyai University, Department of Geology, 1 M. Kogălniceanu Str., 400084 Cluj-Napoca, Romania; sergiu.serban@ymail.com; cristianvictormircescu@hotmail.com

${ }^{2}$ Babeş-Bolyai University, Department of Geology and Center for Integrated Geological Studies, 1, M. Kogălniceanu str., 400084

Cluj-Napoca, Romania; ioan.bucur@ubbcluj.ro;

${ }^{3}$ Independent researcher; navzar22@yahoo.com

* Corresponding author
} 


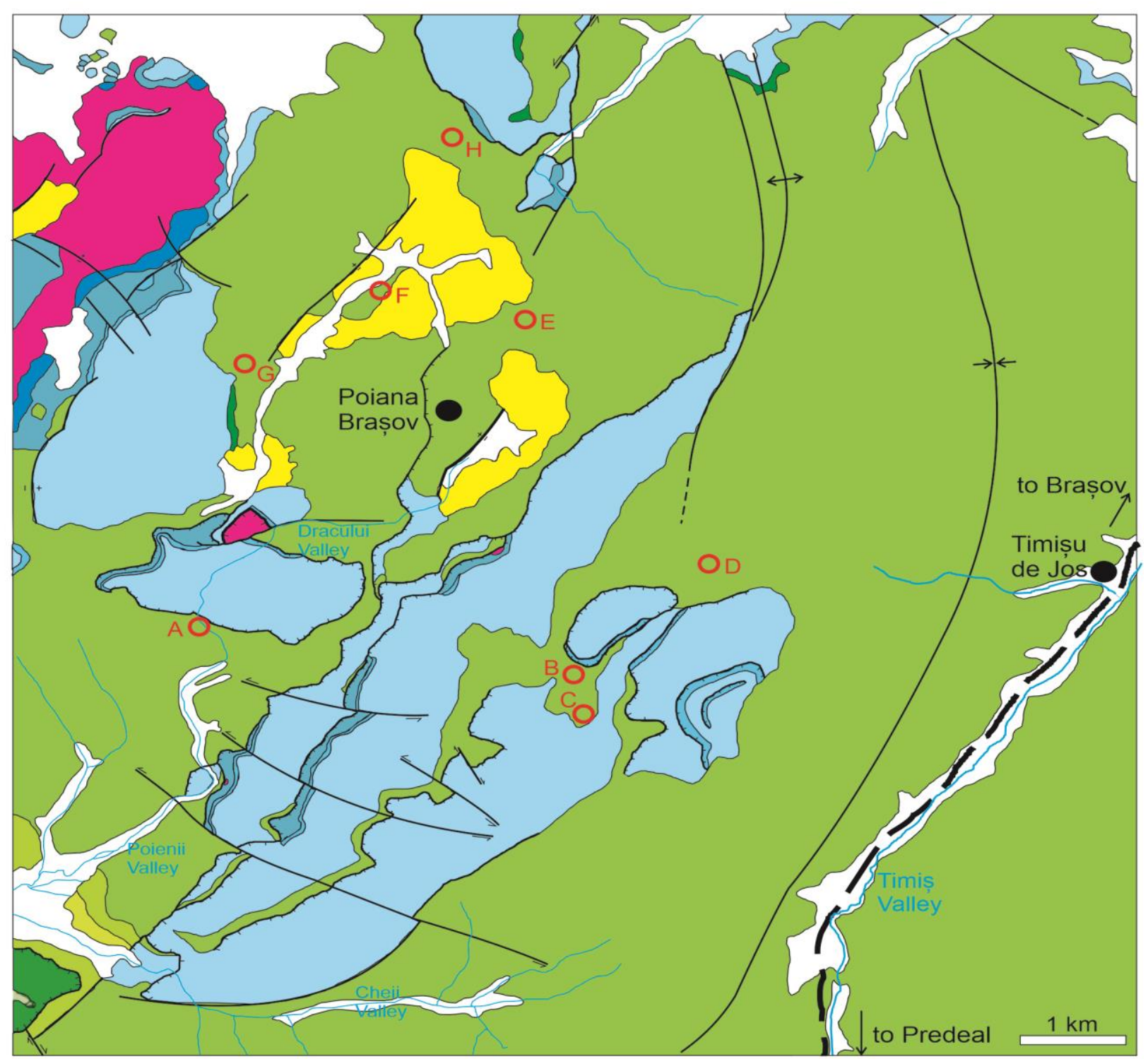

\section{LEGEND}
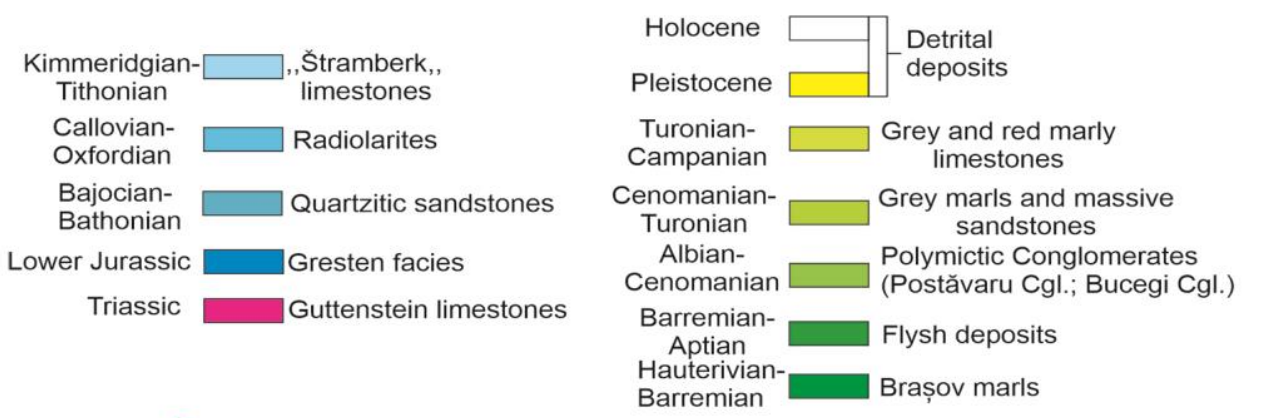

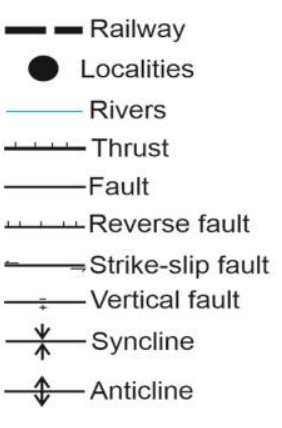

O Studied sections: A- Groapa Dracului; B- Poiana Ruia; C - Cabana Postăvaru; D - Lamba Mare E - Poiana Brașov - Poiana Mare; F - Poiana Mare; G - Poiana Cristianului; H - Road to Brașov

Fig. 1 Location of studied sections on the geological map of the Postăvaru Compartment (modified from Săndulescu et al., 1972)

processes. This succession is distributed within all four compartments defining the tectonic structure of the Postăvaru Massif (Săndulescu, 1964) (Fig. 1; Fig. 2a-b). These tectonic units are represented by the Postăvaru, Braşov, Cristian and Râşnov compartments. Triassic deposits are present only in the Cristian and Brașov tectonic units. They consist of Anisian (Guttenstein-type) lime- stones and Ladinian reef limestones. These deposits are overlain by Lower Jurassic (Gresten-type) sandstones, which form good outcrops in the same compartments as the Triassic deposits. White quartz rich sandstones define the Toarcian and the basal part of the Middle Jurassic sequence (Aalenian-Bajocian), which is equally distributed in the Cristian, Postăvaru and Braşov sedimentary 
areas (sensu Săndulescu, 1964) (Fig. 2a-b). BathonianUpper Callovian marls and jaspers form the rest of the Middle Jurassic sequence. The marls contain shells of Bositra buchi (Römer) and frequent quartz clasts. The jasper layers are 2-5 m thick, red-greenish to yellow with frequent interbedded limestone packages.

Oxfordian jaspers and radiolarites define the basal part of the Upper Jurassic deposits which form extensive outcrops in all four compartments (Postăvaru, Braşov, Cristian, Râşnov) (Fig. 2a-b). The Kimmeridgian-Tithonian interval is represented by Štramberk type limestones, which are either massive, stratified in thick beds or brecciated (Săndulescu, 1964; Sorescu, 1984).

Berriasian deposits have not been described from the Postăvaru Massif. Săndulescu (1964) suggested the continuity of sedimentation between Tithonian and Berriasian, comparing the sedimentary succession from this area with similar deposits from the adjacent regions (Dâmbovicioara Area, Codlea Zone). However, no micropaleontological or facies data were used to sustain this idea.

Valanginian-lower Aptian marls form the next package of rocks from the middle part of the sedimentary succession. They are covered by upper Albian-lower Cenomanian Postăvaru Conglomerates (Fig. 2a-b). The last are polymictic conglomerates with clasts of limestone, quartzites and other metamorphic rocks. Carbonate fragments are dominant and their cement contains mainly limestone material. The upper Aptian-Albian interval is defined by a stratigraphic gap, which characterizes all four compartments of the Postăvaru Massif. The last term of the sedimentary succession consists of upper Cenomanian-upper Senonian marls (Săndulescu, 1964).

\section{MATHERIALS AND METHODS}

Fieldwork analysis was performed in order to describe the sedimentological characteristics of the conglomerate deposits and to collect clast samples at high resolution. One meter square surfaces were delineated in each outcrop and all samples (carbonate, metamorphic or mixed material) were collected from those areas. Pebble composition was estimated by applying visual analysis techniques. Thin sections were prepared from 150 samples (carbonate clasts and matrix) and some of them were sectioned longitudinally for polished slab preparation. Thin section analysis was performed in order to define the main textures and micropaleontological assemblages of the carbonate clasts. Microfacies description follows the classifications of Dunham (1962) and Embry \& Klovan (1971).

\section{RESULTS}

\section{Outcrop dscription and conglomerate types}

Groapa Dracului (Fig. 1A)

This outcrop consists of carbonate paraconglomerates with more than $95 \%$ carbonate pebbles (Fig. 3a) and sandy to carbonate matrix (Fig. 3b). These deposits are stratified in banks and they lack grading. Clast shape varies from subangular to subrounded and their roundness is irregular (Fig. 3b). Moderate to poorly sorted areas are present within the banks.

Poiana Ruia-Cabana Postăvaru (Fig. 1B-C)

These are poorly sorted, inverse to normal graded polymictic paraconglomerates with more than $95 \%$ carbonate pebbles (Fig. 3c, sequences 1-5). Sub-centimetric to centimetric pebbles are common. Their roundness degree ranges from subangular-angular to subrounded (Fig. 3d). Meter thick tabular beds consist of interbedded coarse layers (Fig. 3e-f, black arrows) and finer levels of sandstones (Fig. 3e-f, white arrows) (Fig. 3e-f).

\section{Poiana Brașov-Poiana Mare (Fig. 1E)}

This outcrop contains mainly polymictic orthoconglomerates with more than $95 \%$ carbonate elements. Clasts dimensions vary from centimetric pebbles to decimetricmetric blocks (Fig. 4a). Metamorphic clasts are composed of quartzites. Subangular to subrounded clasts are dominant and sorting is poor. Millimeter sized clasts may be present within very fine microconglomeratic interbeds.

Poiana Mare-Poiana Cristianului (Fig. 1F-G)

These are massive strongly cemented, moderately sorted polymictic paraconglomerates with carbonate-siliciclastic matrix and more than $80 \%$ carbonate clasts (Fig. 4b). Centimeter thick carbonate clasts have rounded to wellrounded shapes (Fig. 4b). The metamorphic components consist of subrounded fragments of quartzites. The coarse carbonate pebbles have isometric (Fig. 4b) or tabular shapes while the fine limestone elements have a flattened aspect (Fig. 4b).

Lamba Mare (Fig. 1D)

Meter-thick bedded (Fig. 4c) polymictic orthoconglomerates define this location. They are composed of a sandycarbonate matrix with more than $90 \%$ carbonate clasts. Grading is absent, and clast roundness ranges from subrounded to rounded. Small $(3-4 \mathrm{~cm})$ carbonate elements are sourced mainly from fine, micritic deep-water deposits. Metamorphic clasts are represented by very wellrounded fragments of quartzites.

Road to Braşov (Fig. 1H)

Poor to well sorted normally graded to ungraded polymictic paraconglomerates are present in this location (Fig. 4d). They contain areas with moderate sorting (Fig. 4d). 

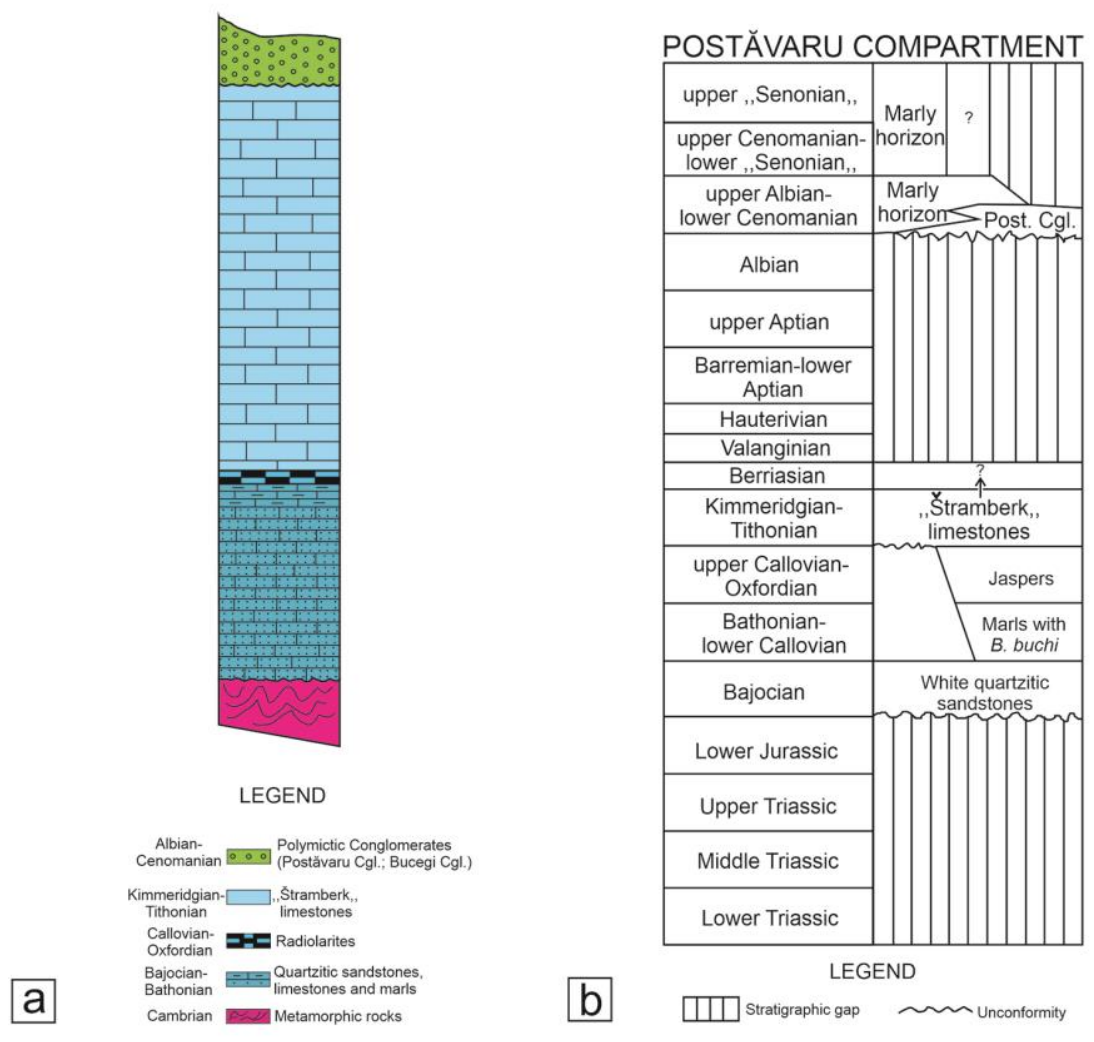

Fig. 2 Sedimentary succession from the Postăvaru Compartment: a Synthetic lithological column of the Mesozoic deposits from the vicinity of Postăvaru Summit (not at scale); b Vertical distribution and lithology of the sedimentary succession from the Postăvaru Compartment [from Săndulescu, 1964 and Săndulescu et al. (1972), with changes]

Carbonate clasts: microfacies and microfossils

The existing microfacies point to three major clast categories (a-c) with different facies types and micropaleontological associations. Carbonate clasts are dominant within all studied outcrops.

\section{Clast category A}

Facies types include peloidal rudstones with encrusting organisms (Fig. 5b), coral-microbial microencruster boundstone (Fig. 5a) and pel-bioclastic grainstones/rudstones (Fig. 5d). The coral-microbialmicroencruster boundstones contain abundant micritic intraclasts and stromatolitic structures (Fig. 5a). The grainstone/rudstone facies are poorly sorted and they contain mainly coral fragments and echinoid fragments (Fig. $5 \mathrm{~b}, \mathrm{~d})$. Corals are encrusted by microproblematic organisms and the internal sediment is composed of peloidal wackestone. The micropaleontological association contains mainly encrusting organisms [Crescentiella morronensis (Crescenti) (Fig. 6a-b), Labes atramentosa Eliašova (Fig. 6c-d), Lithocodium type crusts (Fig. 6e) , Koskinobulina socialis Cherchi \& Schroeder, Taumathoporella parvovesiculifera (Raineri), Terquemella sp.], worm tubes, echinoderm plates, calcareous sponges [Neuropora lusitanica Termier, Termier and Ramalho, Perturbatacrusta leini Schlagintweit \& Gawlick, (Fig. 6f)], foraminifera [Coscinophragma sp. (Fig. 7a), Coscinoconus alpinus Leupold (Fig. 7c), Frentzenella involuta (Mantsurova) (Fig. 7d), Labyrinthina mirabilis Weynschenk (Fig. 7b), Mohlerina basiliensis (Mohler) (Fig. 7e)], gastropods and bivalves.

Clast category B

These pebbles contain mainly mudstone-wackestone to packstone with pelagic bivalves and calpionellids (Fig. $5 \mathrm{~g}-\mathrm{h}$ ) or silicified wackestone/packstone facies types (Fig. 5c). The most important microfossils are represented by pelagic microorganisms (Calpionella alpina Lorenz; Crassicolaria parvula Remane) (Fig. 7 h-i). Other bioclasts include thin pelagic shell bivalves or sponge spicules. Some samples contain echinoderm plates and evidence of bioturbation. Partial or total silicifiation affects the wackestone-packstone type carbonate pebbles.

\section{Clast category $\mathrm{C}$}

These pebbles contain the following facies types: peloidal bioclastic intraclastic grainstone (Fig. 5d), peloidal ooidic grainstone, fenestral bioclastic wackestone (Fig. 5e) and fenestral wackestone with vadoids (Fig. 5f).

The micropaleontological association contains dasycladalean algae [Aloisalthella sulcata (Alth)] and foraminifera [Coscinoconus alpinus (Leupold), Coscinoconus 

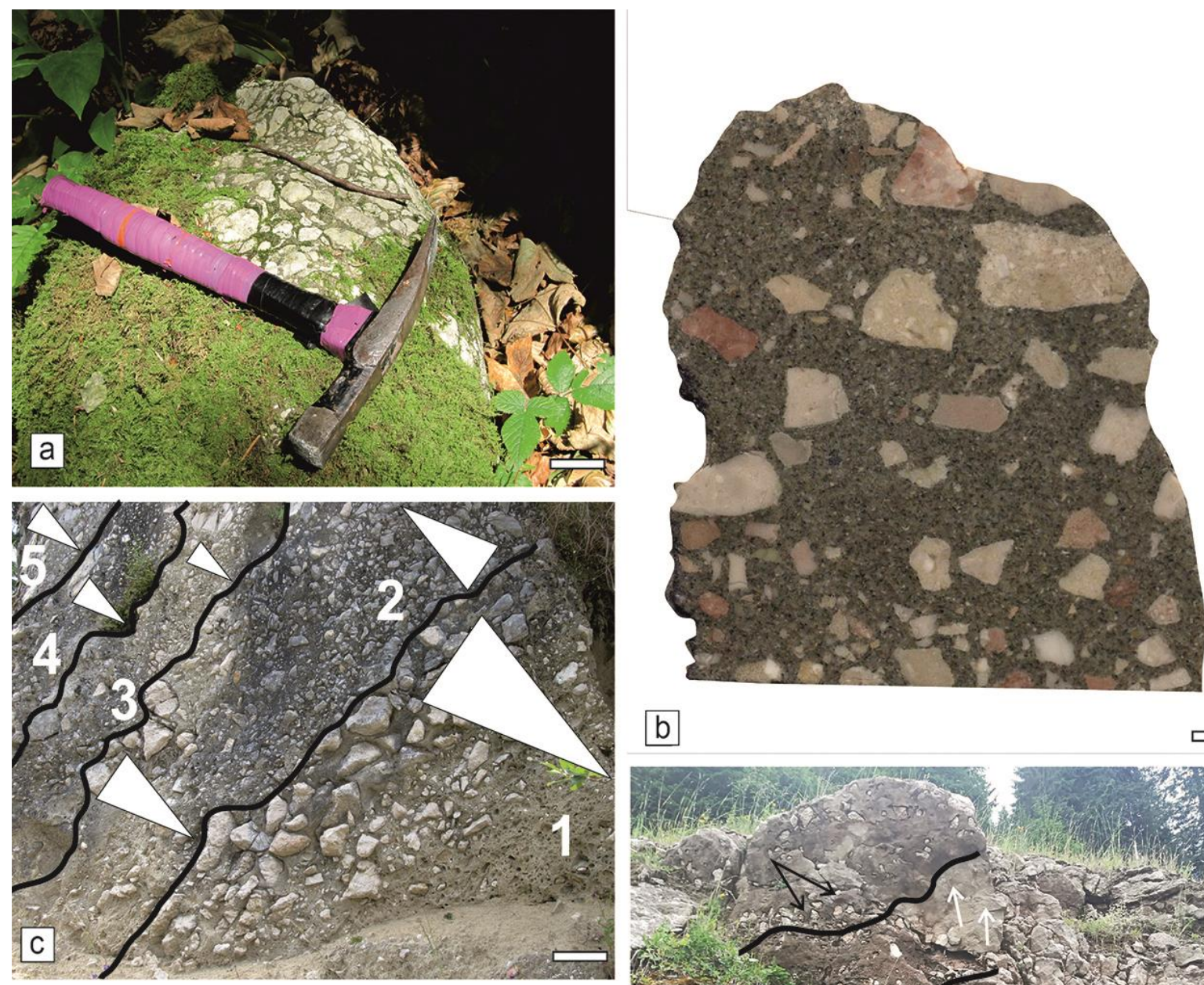

$\mathrm{b}$
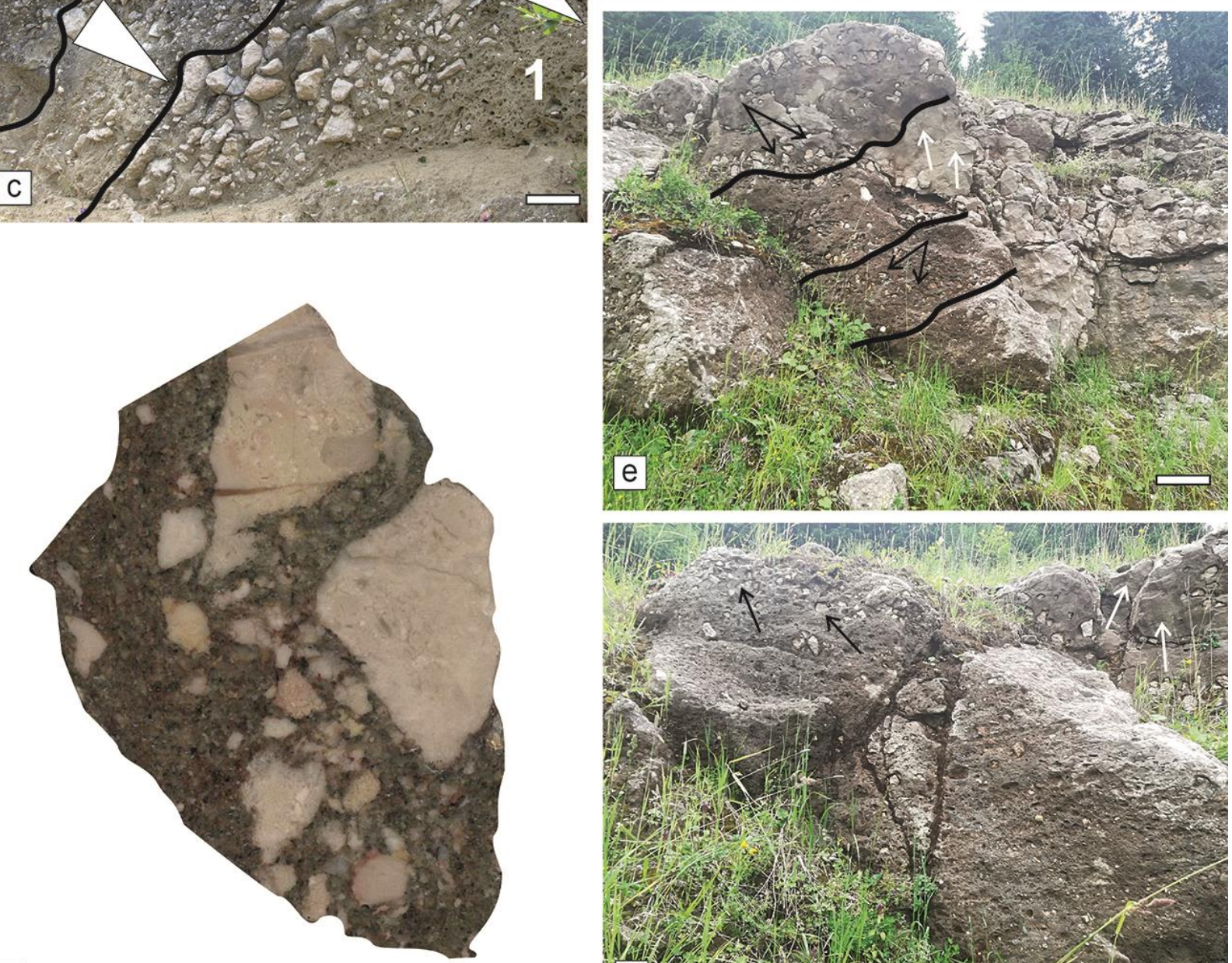

d

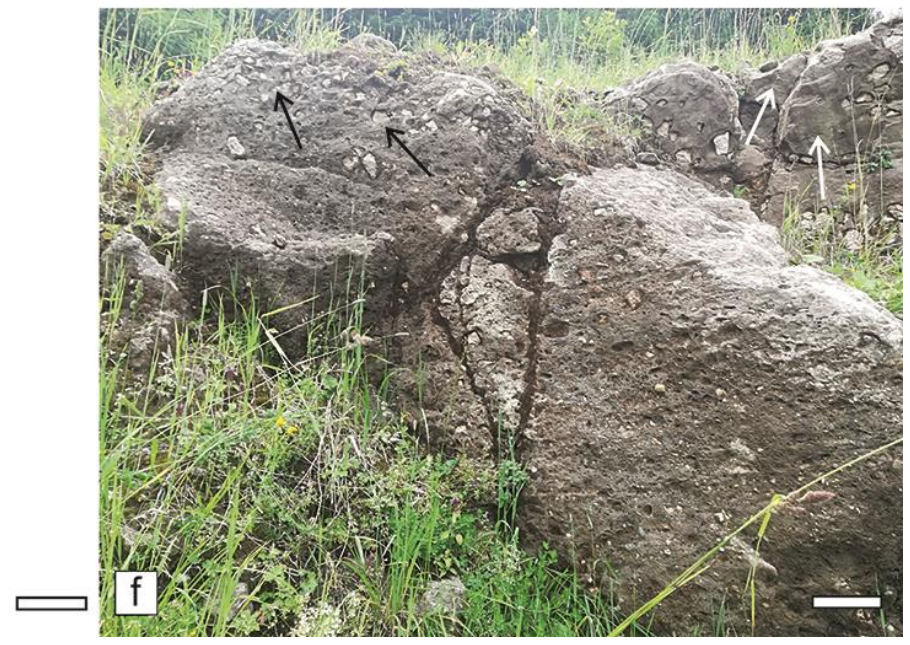

Fig. 3 Field images of the studied outcrops: a Centimeter to decimeter thick banks of carbonate paraconglomerates with abundant carbonate clasts; b Carbonate paraconglomerate with carbonate-sandy matrix and subangular to subrounded clasts; c Normal to inversely graded polymictic paraconglomerates with subangular clasts (sequences 1-5). Lateral transition from normal to inverse grading is evident in sequence 5; $\mathbf{d}$ Polymictic paraconglomerate with more than 95\% carbonates and subangular-angular to subrounded clasts; e-f Conglomerate banks consisting of coarse levels (black arrows) and finer sandy interbeds (white arrows); Scale bar: a, b, d $5 \mathrm{~cm} ;$ c $50 \mathrm{~cm} ; \mathbf{e} 50 \mathrm{~cm} ; \mathbf{f} 10 \mathrm{~cm}$. Sections: a-b Groapa Dracului; c Cabana Postăvaru; d-f Poiana Ruia. 

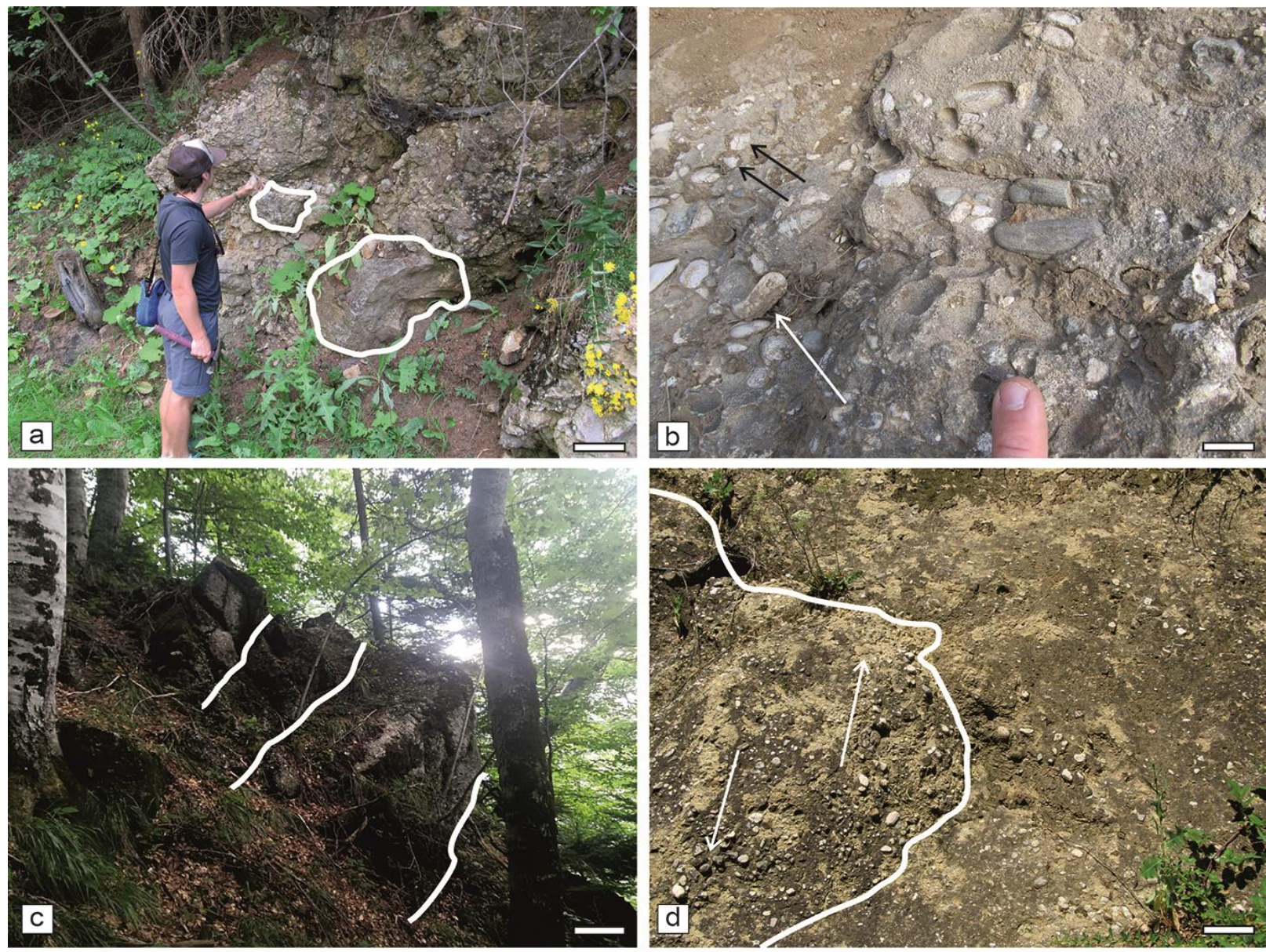

Fig. 4 Field images of the studied outcrops: a Clasts with dimension ranging from centimetric pebbles to decimetric-metric blocks (white circles); b Polymictic paraconglomerates with carbonate-siliciclastic matrix and more than $80 \%$ carbonate clasts. Millimeter to centimeter thick quartzitic fragments are present. Isometric shapes (black arrows) define the coarse pebbles. The fine limestone elements are flattened (white arrows); c Meter thick orthoconglomerate banks (white lines); d Poorly to well sorted polymictic paraconglomerates with centimeter thick clasts. Moderately sorted areas are present (white arrows). Scale bar: a $10 \mathrm{~cm}$; b $5 \mathrm{~cm} ; \mathbf{c}$ - d $50 \mathrm{~cm}$. Sections: a Poiana Brașov-Poiana Mare; b Poiana Mare; c Lamba Mare; d Road to Brașov.

delphinensis (Arnaud-Vanneau et al.) (Fig. 7f), Lituola baculiformis Schlagintweit \& Gawlick, Protopeneroplis ultragranulata (Gorbachik) (Fig. 7g)]. The grainstone facies types contain corals, bivalves, gastropods and crustaceans (Carpathocancer sp.). Corals are encrusted by Bacinella type structures and Lithocodium type crusts. Micritic envelopes surround coral fragments (Fig. 5d) and cyanobacteria nodules are frequent (Fig. 5d). Void margins are bordered by dog-tooth cement and their filling consists of very fine vadose silt. Laminoid-fenestral wackestone facies contain menicus cement (Fig. 5e). Cyanobacteria nodules form the vadoids nuclei (Fig. 5f).

\section{DISCUSSION}

Depositional environments and source areas of the carbonate clasts

The conglomerate deposits from the northern part of the studied area (Poiana Mare, Lamba Mare) contain deepwater Tithonian-Berriasian pelagic clasts. Reef or inner platform clasts are scarce. By contrast, the southern part contains mainly Upper Jurassic-Lower Cretaceous reefal and inner platform reworked carbonate material. Roundness degree and sorting is different in all studied outcrops. Angular to subangular clasts characterize the southern part of the studied area (Ruia, Cabana Postăvaru, Groapa Dracului) while the northern part (Poiana Mare, Lamba Mare, Road to Brașov) contains well to very well rounded carbonate elements. All this data indicate that carbonate clasts were sourced from different areas through variable transport distances. The identified microfacies characterize a wide spectrum of depositional environments, ranging from basin to reef flanks and inner-platform settings. Clast category A is typical for reef slopes and platform margin bioconstructions. Clast category B is typical for distal slope and basin environments. Clast category $\mathrm{C}$ characterises platform margin areas or inner platform settings (intertidal to supratidal areas).

\section{BIOSTRATIGRAPHIC REMARKS}

The microfossil assocation of clast category A is typical for the Kimmeridgian-Tithonian interval. Crescentiella 

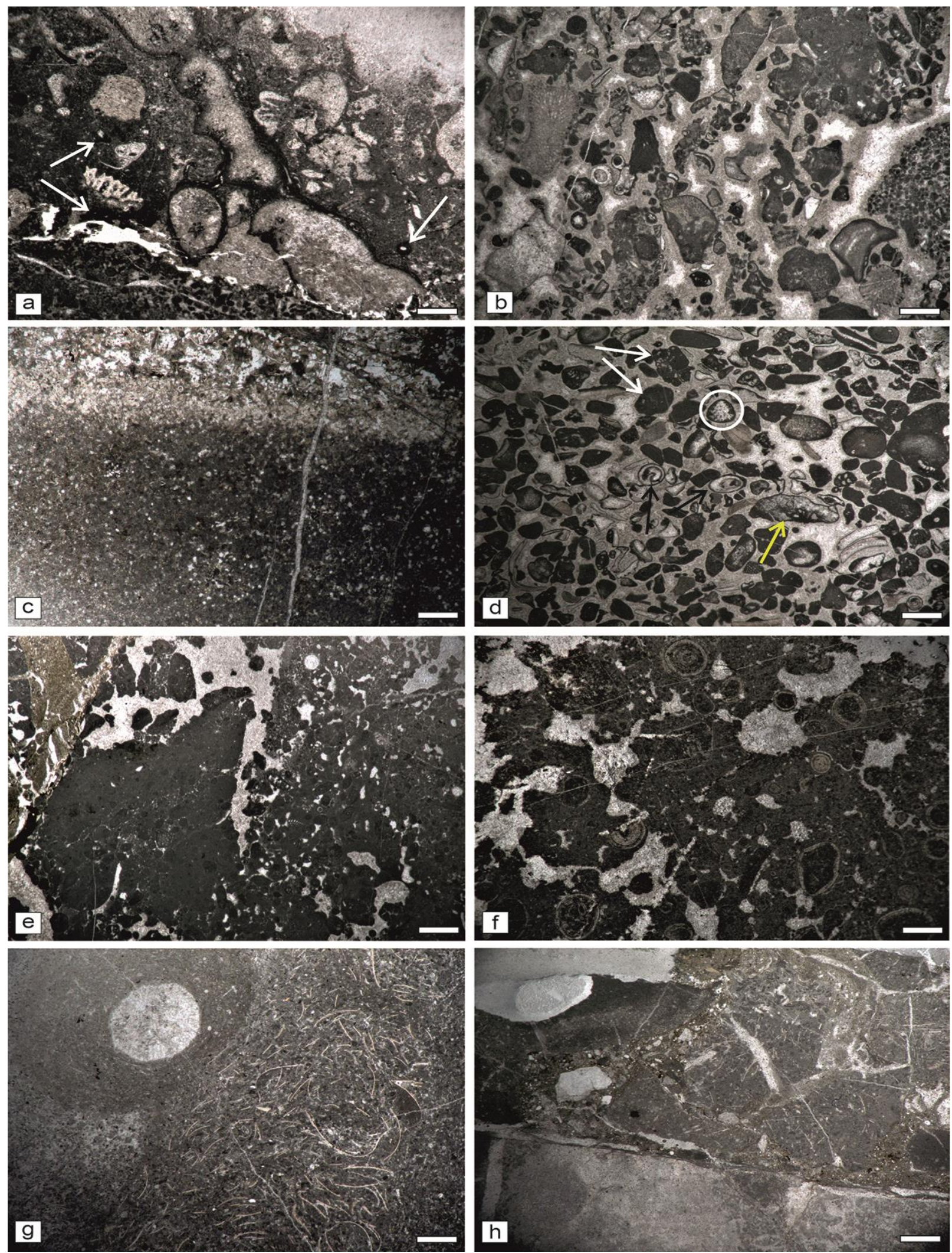

Fig. 5 Microfacies characteristics of the carbonate clasts from the Postăvaru Conglomerates: a Coral-microbial boundstone. Notice the peloidal wackestone-packstone internal sediment with encrusting organisms (Crescientella morronensis) (white arrows); b Bioclastic intraclastic rudstone with encrusting organisms and calcareous sponges; c Silicified packstone; d Coarse bioclastic grainstone. It contains coral fragments (yellow arrows), foraminifera (Coscinoconus alpinus) (white circle), cyanobacteria nodules (white arrows), gastropods (black arrows) and bivalves; e Fenestral wackestone-packstone with rare foraminifera and cyanobacteria nodules; f Wackestone with vadoids; $\mathbf{g}$ Packstone with filamentous pelagic bivalves and rare calpionellids; $\mathbf{h}$ Contact between pelagic wackestone-packstone and peloidal grainstone type pebbles. Scale bar: a-h $1 \mathrm{~mm}$. Samples: a 2264; b 2129; c 2290; d 2125; e 2248; f 2268; g 2350; h 2337. Sections: a, e-f Groapa Dracului; b, d Poiana Ruia; c Lamba Mare; g-h Poiana Brașov-Poiana Mare. 

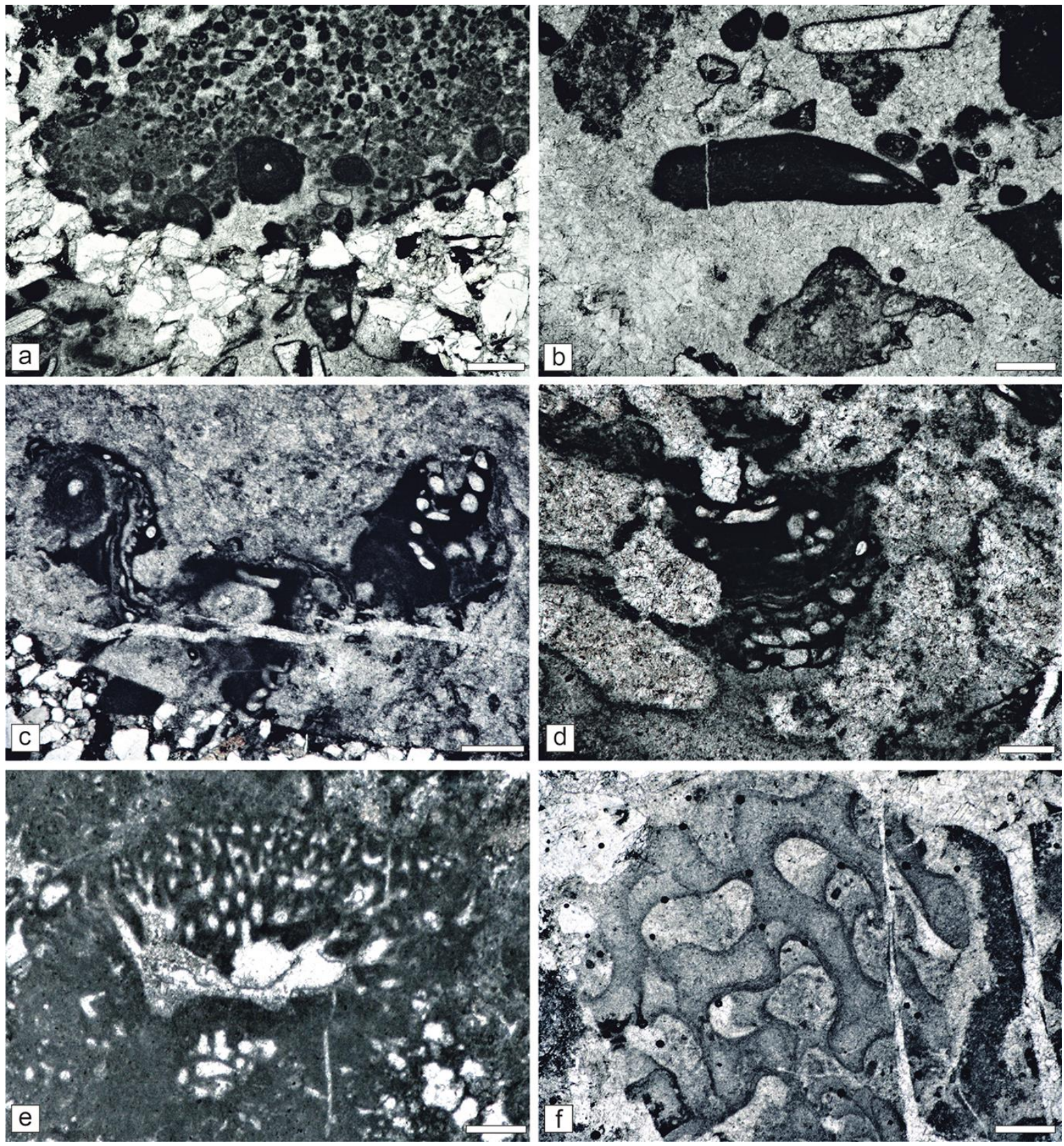

Fig. 6 Encrusting organisms identified in the carbonate clasts from the Postăvaru Conglomerates: a-b Crescentella morronensis; c-d Labes atramentosa; e Lithocodium type crust with entobian borrings; f Perturbatacrusta leini. Scale bar: a-f 0.5 mm. Samples: a 2241; b 2129; c 2357; d 2119; e 2257; f 2116. Sections: a, e Groapa Dracului; b, d, f Poiana Ruia; c Poiana Mare.

morronensis has a broad stratigraphic distribution. It is very well known from Upper Jurassic-Lower Cretaceous deposits (Leinfelder et al., 1993; Schlagintweit et al., 2005; Senowbari-Daryan et al., 2008; Pleş et al., 2017).

Koskinobulina socialis is an encrusting organism known from Triassic (Carnian) to Paleocene deposits (SánchezBeristain et al., 2013; Pleș et al., 2017).

Lithocodium aggregatum is a microproblematic organism which is well known from upper Oxfordian to Upper Cretaceous deposits (Védrine, 2008; Schlagintweit \& BoverArnal, 2010; Pleș et al., 2017). However, it was frequently described from Upper Jurassic (KimmeridgianTithonian) deposits (Leinfelder et al., 1993; Schmid
\& Leinfelder, 1996). Most of what was described as Lithocodium aggregatum from Jurassic carbonates represent in fact entobian borrings (Schlagintweit et al., 2010), as in the present study.

Perturbatacrusta leini is an encrusting calcified sponge described mainly from Kimmeridgian-Berriasian carbonates (Schlagintweit \& Gawlick, 2011; Pleș \& Schlagintweit, 2013).

Coscinoconus alpinus and Mohlerina basiliensis are frequently reported from Upper Jurassic (KimmeridgianTithonian) deposits in association with different species of encrusting organisms (Bucur et al., 2014). From all these taxa, Labyirinthina mirabilis is the most 


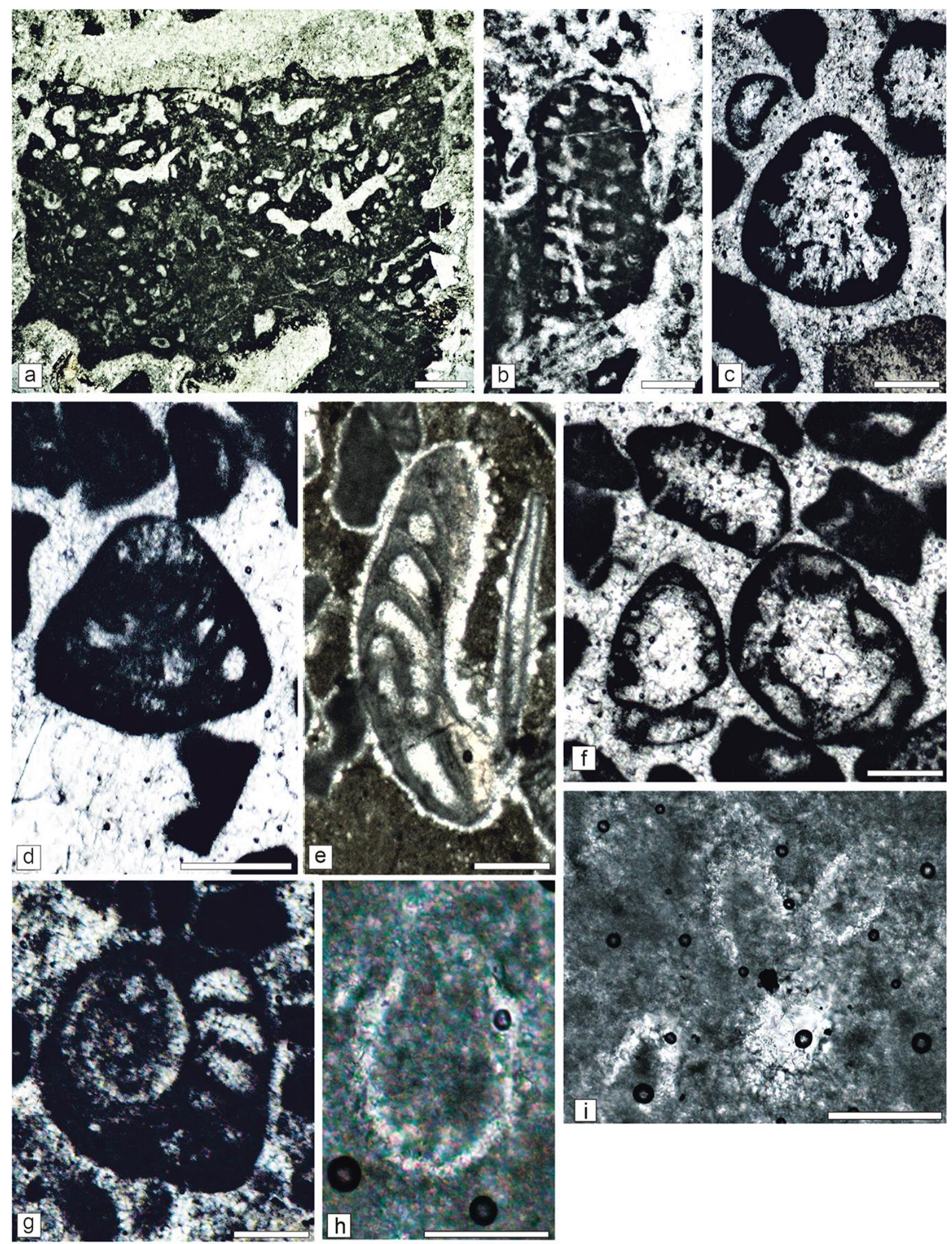

Fig. 7 Foraminifera and pelagic microfossils identified in the carbonate clasts from the Postăvaru Conglomerates: a Coscinophragma sp.; b Labyrinthina mirabilis; c Coscinoconus alpinus; d Frentzenella involuta; e Mohlerina basiliensis; f Coscinoconus delphinensis; $\mathbf{g}$ Protopeneroplis ultragranulata; $\mathbf{h}$ Calpionella alpina; i Crassicolaria parvula. Scale bar: a-f $0.5 \mathrm{~mm}$; g-i $0.25 \mathrm{~mm}$. Samples: a, c 2241; b 2124; d 2137; e, g 2251; f 2253; h-i 2125. Sections: a, c, e, f, g Groapa Dracului; b, d, h-i Poiana Ruia. 
Table 1 Stratigraphic table containing the facies types from the easternmost part of the Getic Carbonate Platform based on Săndulescu (1964), Patrulius (1969), Bucur et al. (2014), Grădinaru et al. (2016), Săsaran et al. (2017) and Mircescu et al. (2019).

\begin{tabular}{|c|c|c|c|c|}
\hline Age & $\begin{array}{l}\text { Piatra Craiului } \quad- \\
\text { Dâmbovicioara }\end{array}$ & Codlea Region & $\begin{array}{l}\text { Western Part of } \\
\text { Bucegi Massif }\end{array}$ & $\begin{array}{l}\text { Postăvaru Massif } \\
\text { (this study) }\end{array}$ \\
\hline Cenomanian & \multirow{2}{*}{$\begin{array}{l}\text { Conglomerates with } \\
\text { carbonate olistoliths }\end{array}$} & \multirow{2}{*}{$\begin{array}{l}\text { Polymictic conglom- } \\
\text { erates }\end{array}$} & - & \multirow[t]{2}{*}{$\begin{array}{l}\text { Polymictic conglomer- } \\
\text { ates and marls }\end{array}$} \\
\hline Albian & & & \multirow{2}{*}{$\begin{array}{l}\text { Polymictic con- } \\
\text { glomerates with } \\
\text { carbonate blocks } \\
\text { and olistoliths }\end{array}$} & \\
\hline Aptian & $\begin{array}{l}\text { Massive conglomer- } \\
\text { ates, sandstones and } \\
\text { microconglomerates }\end{array}$ & $\begin{array}{l}\text { Massive conglomer- } \\
\text { ates }\end{array}$ & & \multirow{4}{*}{ Marls } \\
\hline Barremian & $\begin{array}{l}\text { Marls and biocon- } \\
\text { structions }\end{array}$ & Marls & - & \\
\hline Hauterivian & Marls & Marls & \multirow{3}{*}{$\begin{array}{l}\text { Deep water marls, } \\
\text { slope carbonates } \\
\text { with ammonites, } \\
\text { calpionellids, on- } \\
\text { coids and ooids }\end{array}$} & \\
\hline Valanginian & \multirow{2}{*}{$\begin{array}{l}\text { Inner platform car- } \\
\text { bonates (peritidal } \\
\text { mudstone to wack- } \\
\text { estone-packstone and } \\
\text { grainstone) and marls }\end{array}$} & \multirow{2}{*}{$\begin{array}{l}\text { Shallow water car- } \\
\text { bonates (bioclastic } \\
\text { rudstone), } \\
\text { hardgrounds, pelagic } \\
\text { carbonates (mud- } \\
\text { stone/wackestone with } \\
\text { pelagic microfossils) }\end{array}$} & & \\
\hline Berriasian & & & & $\begin{array}{l}\text { ? (Possible presence of } \\
\text { slope carbonates and } \\
\text { shallow water, inner } \\
\text { platform limestones) }\end{array}$ \\
\hline Tithonian & \multirow{2}{*}{$\begin{array}{l}\text { Shallow water, plat- } \\
\text { form margin car- } \\
\text { bonates (bioclastic } \\
\text { rudstone, bioconstruc- } \\
\text { tions and bioclastic } \\
\text { shoals) }\end{array}$} & \multirow{2}{*}{$\begin{array}{l}\text { Shallow water car- } \\
\text { bonates (bioconstruc- } \\
\text { tions and bioclastic } \\
\text { rudstone) }\end{array}$} & \multirow{2}{*}{$\begin{array}{l}\text { Deep water and } \\
\text { slope carbonates } \\
\text { with pelagic or- } \\
\text { ganisms, microbi- } \\
\text { al structures, ooids } \\
\text { and oncoids }\end{array}$} & \multirow{2}{*}{$\begin{array}{l}\text { Bioconstructions } \\
\text { coarse bioclastic grain- } \\
\text { stone/rudstone, wack- } \\
\text { estone/floatstone with } \\
\text { calpionellids and reef } \\
\text { fragments }\end{array}$} \\
\hline Kimmeridgian & & & & \\
\hline
\end{tabular}

representative for the Kimmeridgian-lower Tithonian interval (Septfontaine, 1988; Velić, 2007).

Clast category B contains mainly Tithonian-Berriasian deep water, pelagic microfossils. Calpionella alpina and Crassicolaria parvula were frequently described from Tithonian-Berriasian (Remane et al., 1986; Pop, 1994, 1997; Lakova et al., 1999; Lakova \& Petrova, 2013) pelagic deposits. Calpionella alpina characterizes the upper Tithonian-lower Valanginian while Crassicolaria parvula is typical for the upper Tithonian-lower Berriasian interval (Michalík \& Reháková, 2011; Atasoy et al., 2018; Scott, 2019). The relatively high frequence of $\mathrm{Cal}$ pionella alpina indicate rather an early Berriasian age. Lower Cretaceous shallow water microfossils characterize clast category $\mathrm{C}$. The vast majority of these microfossils have a long stratigraphic distribution. Aloisalthella sulcata was described from Kimmeridgian-Berriasian deposits (Bassoullet, 1997; Bucur, 1999; Mircescu et al., 2014; Granier \& Lethiers, 2019). Protopeneroplis ultragranulata is known from middle Tithonian-Barremian deposits with high frequency in Berriasian-Valanginian carbonate rocks (Altiner, 1991; Bucur, 1997). Only Coscinoconus delphinensis is frequently cited from Berriasian-Valanginian deposits (Arnaud-Vanneau et al., 1988; Mancinelli \& Coccia, 1999) even if some authors (Schlagintweit \& Ebli, 1998) mention this species from the uppermost Tithonian. However, the whole assemblage points to a Berriassian, possibly early Valanginian age.

Similar facies types are present in adjacent regions such as Dâmbovicioara zone, Piatra Craiului Mountains, or the Bucegi Massif (Bucur et al., 2009; Pleș et al., 2013; Grădinaru et al., 2016; Mircescu et al., 2019) (Table 1). These regions may have represented the source area of the carbonate material. However, future studies are necessary in order to define clearly the source area of the carbonate clasts of these conglomerates. Paleocurrent measurements, morphometric analysis, and detailed petrographical analysis of non-carbonate elements are necessary in a future studies. 


\section{CONCLUSIONS}

The studied conglomerates have heterogeneous properties in terms of sedimentological and facies characteristics, in all the studied outcrops. Carbonate clasts were reworked from a large variety of depositional environments (basin to inner platform domains). They were most probably sourced from adjacent regions (Piatra Craiului, Dâmbovicioara, Bucegi) or even from the carbonate successions belonging to the Postăvaru Massif (Cristian, Râșnov and Brașov Compartments).

The identified microfosssils indicate three major biostratigraphic intervals: Kimmeridgian-Tithonian, TithonianBerriasian and Berriasian-?early Valanginian.

Two major types of conglomerates are defined based on their sedimentological and facies characteristics. The first category includes polymictic conglomerates with well rounded deep-water carbonate clasts while the second cathegory includes polymictic conglomerates with angular, reefal to inner platform carbonate elements.

\section{AKNOWLEDGEMENTS}

Reviewers Michael Kamiski and George Pleș are thanked for their valuable suggestions that helped to improve a previous version of the manuscript. This study is a contribution to the Special Scholarship for Scientific Activity awarded by the Babeș-Bolyai University, 2019-2020 Programme to the first author (Sergiu Șerban). It is also a contribution to a grant of the Romanian Ministry of Education and Research, CNCS-UEFISCDI project number PN-III-P1-1.1-PD-2019-0456, within PNCDI III (corresponding author - Cristian Victor Mircescu).

\section{REFERENCES}

Altiner, D., 1991. Microfossil biostratigraphy (mainly foraminifers) of the Jurassic-Lower Cretaceous carbonate successions in north-western Anatolia (Turkey). Geologica Romana, 27: 167-213.

Atasoy, G.S., Altiner, D. \& Okay, A.I., 2018. Reconstruction of a Late Jurassic-Early Cretaceous carbonate platform margin with composite biostratigraphy and microfaces analysis (western Sakarya Zone, Turkey): paleogeographic and tectonic implications. Cretaceous Research, 92: 66-93.

Arnaud-Vanneau, A., Boisseau, T. \& Darsac, C., 1988. Le genre Trocholina Paalzow 1922 et ses principales espèces au Crétacè. Revue de Paléobiologie, 2: $353-$ 377.

Bassoullet, J.P., 1997. Foraminiféres. Les grands foraminiféres. In: Groupe français d'étude du Jurassique - Biostratigraphie du Jurassique ouest-européen et méditerranée: zonations paralleles et distribution des invertébrés et microfossiles. In: Cariou, E \& Hantzpergue P. (eds.) Bulletin du Centre de Re- cherches Elf Exploration Production, Mémoires 17, pp. 293-304.

Bucur, I.I., 1978. Microfacies of the white limestones from the northern part of the Piatra Craiului Massif. Biostratigraphic considerations (in Romanian). Dări de Seamă ale Şedinţelor Institutului Geologic şi Geofizic, 64: 89-105.

Bucur, I.I., 1997. Representatives of the genus Protopeneroplis (Foraminifera) in the Jurassic and Lower Cretaceous deposits in Romania. Comparisons with other regions of the Tethyan area. Acta Paleontologica Romaniae, 1: 65-74.

Bucur, I.I., 1999. Stratigraphic significance of some skeletal algae (Dasycladales, Caulerpales) of the Phanerozoic. In: Farinacci, A., Lord, A.R. (eds.) Depositional Episodes and Bioevents, Paleopelagos Special Publication 2, pp. 53-104.

Bucur, I.I., Grădinaru, E., Lazăr, I. \& Grădinaru, M., 2014. Early Cretaceous micropaleontological assemblages from a condensed section of the Codlea Area (Southern Carpathians, Romania). Acta Paleontologica Romaniae, 9 (2): 67-84.

Bucur, I.I., Săsăran, E., Iacob, R., Ichim, C. \& Turi, V., 2009. Upper Jurassic shallow water carbonate deposits from some Carpathian areas: new micropaleontological results. In: Popa, M.E. (ed.) Marine and nonmarine Jurassic: global correlation and major geological events, The 8th Symposium of IGCP 506, Abstracts and Field Guide, University of Bucharest, pp. 13-14.

Dunham, R.J., 1962. Classification of sedimentary rocks according to depositional structure. In: Ham, W.E. (ed.) Memoir 1st Edition, American Association of Petroleum Geologists, Tulsa, Oklahoma, pp. 235-239.

Embry, A.F. \& Klovan, J.E., 1971. Late Devonian reef tract on northwestern Banks Island. Bulletin of the Canadian Society of Petroleum Geology, 19: 730781.

Granier, B. \& Lethiers, A. (2019). Aloisalthella, a new genus of fossil Polyphysacean green algae (Clorophyta, Dasycladales), with notes on the genus Clypeina (Michelin, 1845). Palaeontologia Electronica, 22.2.45: 1-20.

Grădinaru, M., Lazăr, I., Bucur, I.I., Grădinaru, E., Săsăran, E., Ducea, M.N. \& Andrășanu, A., 2016. The Valanginian history of the eastern part of the Getic Carbonate Platform (Southern Carpathians, Romania): Evidence for emergence and drowning of the platform. Cretaceous Research, 66: 11-42.

Herbich, F., 1878. A Székelyföld földtani és őslénytani leirása. Magyar Állami Földtani Intézet évkönyve, 5 (2): 1-302.

Jekelius, E., 1915. A Brassói neokom fauna (A Brassói hegyek mezozoós faunája). Magyar Állami Földtani Intézet évkönyve, 23 (2): 102-124

Jekelius, E., 1916. A délkeleti Kárpátok tithon-faunája (A Brassói hegyek mezozoós faunája). Magyar Állami Földtani Intézet évkönyve, 24 (3): 280-314. 
Jekelius, E., 1920. Geology of the Bran Pass (in Romanian). Dări de Seamă ale Şedinţelor Institutului Geologic al României, 8: 166-185.

Jekelius, E., 1938. Das Gebirge Von Brașov. Anuarul Institutului Geologic al României, 19: 370-408.

Lakova, I. \& Petrova, S., 2013. Towards a standard Tithonian to Valanginian calpionellid 882 zonation of the Tethyan Realm. Acta Geologica Polonica, 63: 201-221

Lakova, I., Stoykova, K. \& Ivanova, D., 1999. Calpionellid, nannofossil and calcareous dinocyst bioevents and integrated biochronology of the Tithonian to Valanginian in the Western Balkanides, Bulgaria. Geologica Carpathica, 50 (2): 151-168.

Leinfelder, R., Nose, M., Schmid, U.D. \& Werner, W., 1993. Microbial crusts of the Late Jurassic: composition, palaeoecological significance and importance in reef construction. Facies, 29: 195-230.

Mancinelli, A. \& Coccia, B., 1999. Le Trocholine dei sedimenti mesozoici di platforma carbonatica dell'Appennino-centro-meridionale (Abruzzo e Lazio). Revue de Paléobiologie, 18: 147-171.

Meschendorfer, J., 1860. Die Gebirgsarten im Burzenlande, ein Beitrag zur Geognosie von Siebenbürgen. Siebenbürgischer Verein für Naturwissenschaften Hermannstadt, 11: 255-287.

Michalík, J. \& Reháková, D., 2011. Possible markers of the Jurassic/Cretaceous boundary in the 903 Mediterranean Tethys: a review and state of art. Geoscience Frontiers, 2(4): 475-490.

Mircescu, C.V., Bucur, I.I. \& Săsăran, E., 2014. Dasycladalean algae from Upper Jurassic-Lower Cretaceous limestones of Piatra Craiului Massif (South Carpathians, Romania) and their relationship to paleoenvironment. Studia Universitatis Babeș-Bolyai Geologia, 59 (1-2): 5-27.

Mircescu, C.V., Bucur, I.I., Săsăran, E., Pleș, G., Ungureanu, R. \& Oprișa, A., 2019. Facies evolution of the Jurassic-Cretaceous transition in the Eastern Getic Carbonate Platform: Integration of sequence stratigraphy, biostratigraphy and isotope stratigraphy. Cretaceous Research, 99: 71-95.

Oncescu, N., 1943. Région de Piatra Craiului-Bucegi. Étude géologique. Anuarul Institutului Geologic al României, 9: 3-124.

Patrulius, D., 1969. Geologia Masivului Bucegi şi a Culoarului Dâmbovicioara. Editura Academiei RSR, Bucureşti, $321 \mathrm{pp}$.

Patrulius, D., Popa, E., Avram, E., Baltreş, A., Pop, G., Iva, M., Antonescu, E.M., Dumitrica, P. \& Iordan, M., 1980. Complex petrological and biostratigraphical study of the Jurassic and Neocomian formations from the Romanian Carpathians and Dobrudja for the evaluation of the mineral resource potential of the LeaotaBraşov-Perșani Mountains sector (in Romanian). I.G.G. report, theme 47/1979, 180 p.

Pleș, G. \& Schlagintweit, F., 2013. New data on Perturbatacrusta leini Schlagintweit \& Gawlick, 2011
(Calcareous sponge?) from the Late Jurassic (Tithonian) of the Southern Carpathians, Romania. Acta Paleontologica Romaniae, 9 (2): 3-9.

Pleș, G., Mircescu, C.V., Bucur, I.I. \& Săsăran, E., 2013. Encrusting microorganisms and microbial structures in Upper Jurassic limestones from the Southern Carpathians (Romania). Facies, 59: 19-48.

Pleş, G., Bârtaş, T., Chelaru, R. \& Bucur, I.I., 2017. Crescentiella morronensis (Crescenti) (incertae sedis) dominated microencruster association in Lower Cretaceous (lower Aptian) limestones from the Rarău Massif (Eastern Carpathians, Romania). Cretaceous Research, 79: 91-108.

Pop, G., 1994. Calpionellid evolutive events and their use in biostratigraphy. Romanian Journal of Stratigraphy, 76: 2-24.

Pop, G., 1997. Tithonian to Hauterivian praecalpionellids and calpionellids: bioevents and biozones. Mineralogica slovaca, 29 (4-5): 304-305.

Popescu, I., 1966. Contributions to the knowledge of the stratigraphy and the geological structure of the Piatra Craiului Massif (in Romanian). Dări de Seamă ale Şedinţelor Institutului Geologic al României, 52: 157176.

Remane, J., Bakalova-Ivanova, D., Borza, K., Knauer, J., Pop, G. \& Tardi-Filacz, E. 1986. Agreement on the subdivision of the standard calpionellid zones defined at the II plankton conference, Roma 1970. Acta Geologica Hungarica, 29 (1-2): 5-14.

Sánchez-Beristain, F., López-Esquivel Kranksith, L., García-Barrera, P. \& Reitner, J., 2013. El primer registro de Koskinobullina socialis (Foraminífera) para el Triásico de Europa y sus implicaciones paleoecológicas. Boletín Geológico y Minero, 124: 437-450.

Săndulescu, M., 1964. Geological structure of the Postăvarul-Runcu Massif (Braşov Mountains) (in Romanian). Anuarul Comitetului Geologic, 34 (2): $382-422$.

Săndulescu, M., Patrulius, D., Ștefănescu, M., 1972. Geological Map of Romania, scale 1:50 000, sheet $111 \mathrm{a}-$ Braşov, Institute of Geology, Bucharest.

Săsăran, E., Bucur, I.I., Mircescu, C.V. \& Gheorghiță Ungur, C., 2017. Microfacies analysis and depositional environments of the Tithonian-Valanginian limestones from Dâmbovicioara Gorges (Cheile Dâmbovicioarei), Getic Carbonate Platform, Romania. Acta Paleontologica Romaniae, 13(1): 25-48.

Schlagintweit, F. \& Bover-Arnal, T. 2010. Remarks on Bacinella Radoičić, 1959 (type species B. irregularis) and its representatives. Facies 59 (1): 59-73.

Schlagintweit, F. \& Ebli, O., 1998. Halimeda paucimedullaris n.sp. and Oroseina pletzachensis n. sp., two new calcareous algae from the Upper Cretaceous of the Northern Calcareous Alps. Revue de Paléobiologie, 17: 361-371.

Schlagintweit, F. \& Gawlick, H-J., 2011. Perturbatacrusta leini n. gen., n. sp. a new microencruster incertae sedis (? Sponge) from Late Jurassic to Earli- 
est Cretaceous platform margin deposits of the Northern Calcareous Alps of Austria. Facies, 57(1): 123135.

Schlagintweit, F., Gawlick, H.J. \& Lein, R., 2005. Micropaleontology and biostratigraphy of the Plassen carbonate platform of the type locality (Upper Jurassic to Lower Cretaceous, Salzkammergut, Austria). Journal of Alpine Geology, 47: 11-102.

Schlagintweit, F., Bover-Arnal, T., Salas, R. 2010. New insights into Lithocodium aggregatum Elliott 1956 and Bacinella irregularis Radoičić 1959 (Late Jurassic-Lower Cretaceous): two ulvophycean green algae (?Order Ulotrichales) with a heteromorphic life cycle (epilithic/euendolithic). Facies 56: 509-547.

Schmid, D.U. \& Leinfelder, R.R., 1996. The Jurassic Lithocodium aggregatum-Troglotella incrustans foraminiferal consortium. Palaeontology, 39(1): 2152.

Scott, R.W., 2019. Valanginian Knowles Limestone, East Texas: Biostratigraphy and potential hydrocarbon reservoir. GCAGS Journal, 8: 79-88.

Senowbari-Daryan, B., Bucur, I.I., Schlagintweit, F., Săsăran, E. \& Matyszkiewicz, J. (2008). Crescentiella, a new name for "Tubiphytes" morronensis CRESCENTI, 1969: an enigmatic Jurassic-Cretaceous microfossil. Geologia Croatica, 61 (2-3): 185-214.

Septfontaine, M., 1988. Vers une classification évolutive des Lituolidés (Foraminifères) Jurassiques en milieu de plate-forme carbonatée. Revue de Paléobiologie, Volume Spéciale No. 2, Benthos '86: 229-256.
Sorescu, E., 1984. Upper Jurassic facies in the Postăvaru Massif. Analele Universităţii București, 35: 71-75.

Ungureanu, R., Săsăran, E., Bucur, I.I., Ungur, C.G. \& Mircescu, C.V., 2015. The Berriasian-Valanginian and Aptian deposits from the North Western part of the Piatra Craiului Massif: Stratigraphic relationships, facies and depositional environments. Acta Palaeontologica Romaniae, 11 (2): 59-74.

Ungureanu, R., Săsăran, E., Bucur, I.I., Mircescu, C.V., Ungur, C.G. \& Ungureanu, A., 2017. The Cretaceous conglomerates from Piatra Craiului syncline (South Carpathians, Romania): searching for the source area. Facies, 63 (4): 30.

Ungureanu, R., Săsăran, E., Bucur, I.I., Mircescu, C.V., Ungureanu, A. \& Ungur, C.G., 2019. The Aptian Gura Râului conglomerates (Southern Carpathians): remains of an extended subaqueous gravity flow deposit from the eastern flank of the Getic Nappe. Geological Quarterly, 63 (1): 88-105.

Velić, I., 2007. Stratigraphy and Palaeobiogeography of Mesozoic Benthic Foraminifera of the Karst Dinarides (SE Europe). Geologia Croatica, 60 (1): 1-113.

Védrine, S., 2008. Co-occurrence of the foraminifer Mohlerina basiliensis with Bacinella-Lithocodium oncoids: palaeoenvironmental and palaeoecological implications (Late Oxfordian, Swiss Jura). Journal of Micropalaeontology, 27: 35-44. 